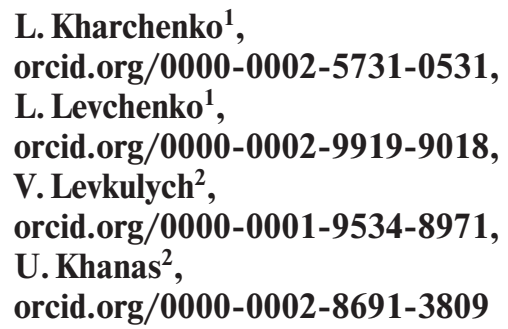

1 - Pereiaslav-Khmelnytskyi Hryhorii Skovoroda State Pedagogical University, Pereiaslav, Ukraine, e-mail: harchenko lora@ukr.net

2 - State University "Uzhhorod National University”, Uzhhorod, Ukraine

\title{
EDUCATION AND HUMAN CAPITAL DEVELOPMENT: FROM STAGNATION TO RECESSION IN THE UKRAINIAN ECONOMY
}

Purpose. To provide the insight into the reasons for the prolonged stagnation and recession in the economy of independent Ukraine based on statistical data.

Methodology. The authors used the methods of descriptive statistics and logical statistics as the main research methods. In addition, the authors used comparative analysis and modeling.

Findings. The main results of the study are as follows:

1. The authors proved the fact of long-term stagnation of the Ukrainian economy which began in 1989 (4,243 USD of Ukraine's GDP per capita) and has lasted to this day. In 2018, Ukraine's GDP per capita amounted to 3,110 USD. The periods throughout 1990-1998, 2008-2009 and 2014-2015 were the periods of recession.

2. The authors proved the fact of underestimation of two key factors of economic development by the governance of Ukraine: education and human capital. According to the World Happiness Report 2019, Ukraine ranks 133rd out of 156 countries of the world, which confirms the dissatisfaction of Ukrainians with the quality of governance.

3. The dependence of economic growth on the growth in the quality of education and human capital was justified.

Originality. Based on statistical studies, the authors substantiated:

1. The fact of long-term economic stagnation in Ukraine, which began in the year when Ukraine gained independence and has lasted to this day.

2. The main reason for the negative scenarios in the development of the Ukrainian economy during the period of independence is the neglect of the relationship between education, human capital and the national economy in the governance model.

Practical value. The results of the study can be used in governance models, as well as economic, behavioral and other models. The study actualizes the value of education and human capital, and proves their impact on the economic growth of the state.

Keywords: human capital, education, management models, national economy, long-term stagnation

Introduction. Recently, in Ukrainian scientific literature, the data from state statistics have been used less and less, though they allow comparing the state of industry, science and social development of Ukraine during the development of the USSR, as the Ukrainian Soviet Socialist Republic, and over the years of independence of Ukraine. In general, the statistical data have been compared since 1990 [1].

The statistical analysis of the development of Ukraine over a longer period of its development, at least allows us to establish: a) the effectiveness of the Ukrainian legislative and executive authorities in different years of independence of Ukraine; b) compare different periods of the history of Ukraine in order to objectively assess the standard of living of the population. The assessment of life quality of Ukrainian citizens indicates the true contribution of the Presidents of independent Ukraine, the Verkhovna Rada of all convocations, as well as the Cabinet of Ministers of all compositions in the development of state authorities and governance.

The history of the state statistical authorities of Ukraine dates back to March 12, 1919, when "The Regulation on Statistical Establishment of Ukraine" was approved [2]. However, despite such an early history, which is represented on the official website of the State Statistics Service of Ukraine, a comparative analysis of the authors revealed the following.

First, the websites of national statistical authorities of highly developed democracies of the world have provided free access to the data on all key areas of vital activity of the states, at least over the past $40-50$ years. These data allow scientists to objectively evaluate the current work of governments, compare its effectiveness in different periods of the state history, and also make forecasts for the socio-economic development

(C) Kharchenko L., Levchenko L., Levkulych V., Khanas U., 2020 of states in the short and long-term forecasting. For example, the official website of the Office for National Statistics of Great Britain provides free access to the micro- and macroeconomic indicators of the development of the UK economy dating back to 1950 , i.e. from the moment when these data first began to be calculated [3]. The specialized commercial Statista platform has published micro- and macroeconomic indicators for Germany from 1986 onwards [4]. By comparison, a similar data set is available on the official website of the State Statistics Service of Ukraine starting only in 2015, although the site itself was created in 1999 [2]. On the Statista platform website, which brings together the outcomes and facts from 600 industries, as well as more than 50 countries, Ukraine and its statistical indicators have been presented only since 2018 .

Second, analysis, as a scientific method, in its turn, involves the use of descriptive statistics and logical statistics. Both statistical methods increase the quality of analysis and, accordingly, the quality of conclusions drawn on its basis. I. Khomenko revealed the possibilities of informal logic in the modern study of argumentation, and also showed the importance of the correlation between the studies using found logical methods and the necessary quality of argumentation and conclusions that drive modern science [5].

However, descriptive and logical statistics are preceded by the collection and organization of statistical data from all spheres of the nation's life. The larger the amount of the data this collection provides, as well as the higher the quality of the data collected, the lower the likelihood of errors in descriptive and logical statistics is. Therefore, the higher the quality of the analysis and the more convincing argumentation of the conclusions are. For this reason, statistical research has been forming the scientific foundation of public policy and governance for nearly a century. 
Statistics serve as a key tool for governance assessment, thanks to which the government and its opponents evaluate the effectiveness of the current activities of all branches of government, as well as adjust management models in all areas of activity, both in the short and long-term prospects.

The aim of the proposed study is to comprehend the reasons for the prolonged stagnation and recession of the economy of independent Ukraine based on available statistics. In the article, the authors will prove:

1. The fact of the long-term economic stagnation of Ukraine, which began in the year when Ukraine gained independence.

2. The main reason for the negative scenarios in the development of the Ukrainian economy during the period of independence is due to the neglect of the connection between education, human capital and the national economy in its governance model.

The influence of education on the quality of human capital and the impact of human capital on the economic growth have been the subject of close scientific study for several decades [6]. All over the world, the obtained results are used as the basis for governance models, as well as economic, behavioral and other models. In the governance models that are practiced in Ukraine, this relationship is neglected. According to the authors, this neglect is one of the main reasons for the long-term economic stagnation of Ukraine.

Results. Nie, et al., in the introduction to their study, noted that the ways to raise awareness of labor safety among the Chinese workers should be considered in the experience of developed countries. Therefore, they used the methods of descriptive and logical statistics as the main ones for the research on safety and labor protection in China. Comparing Chinese and British laws, regulations, as well as educational systems in the issues of labor protection, the authors proved the need for reforming Chinese law, and also identified the priority sequence of this reform [7].

We will use the proposed research structure. First, we will prove the fact of long-term stagnation and recession of the Ukrainian economy.

In the study by A. Gatsenko, a graph of changes in Ukraine's GDP over the period from 1990 to 2010 is presented (Fig. 1) [8].

The study by Gatsenko is dedicated to proving the fact of inefficient governance during the independence of Ukraine. From the graph, we can see that if the GDP of Ukraine in 1990 is considered as a starting point of reference, i.e. 100 percent, then within 20 years of its independence, the best result was achieved only in 2008. It amounted to only 74.2 percent of 1990 GDP.

In the Ukrainian information space, it is difficult to find statistical data that allow comparing macroeconomic indicators of the development of Ukraine as a part of the USSR and over the years of its independence. There is no official statistics [2].

The authors were able to detect these comparisons in the studies of the World Bank. Fig. 2 represents the study on Ukraine's GDP per capita over the period 1987-2018. The data are presented by the World Bank in US dollars at the 2010 exchange rate (Fig. 2) [9].

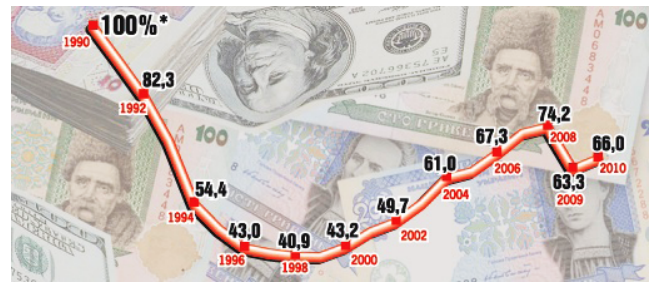

Fig. 1. The ratio of gross domestic product (GDP) of Ukraine, it was taken over the period from 1990 to 2010 as the percentage of GDP in 1990 [8]

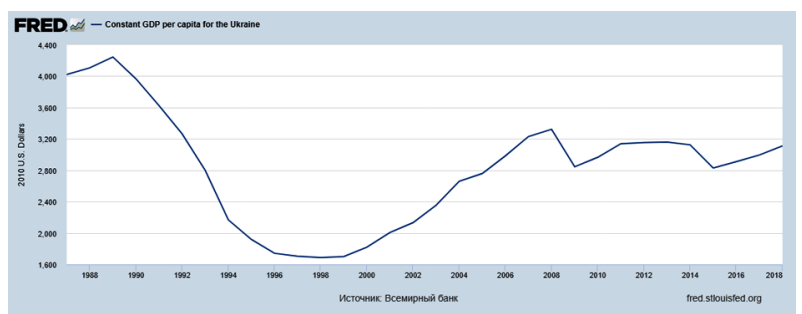

Fig. 2. Constant GDP per capita for Ukraine, 1987-2018 [9]

As we can see, in 1987, GDP per capita at that time in the Ukrainian SSR amounted to 4020 USD, the peak year being 1989 with 4243 USD. In 1990, it accounted for 3965 USD. By the end of Leonid Kuchma's first presidential term, GDP reached its lowest level - 1,686 USD (1998) per capita. From the graph, we can see that over the period of 1990-1998, the Ukrainian economy was in recession. A 10 percent reduction in GDP or recession that lasts three or four years is commonly referred to through the economic term "economic depression". In Ukraine, the recession period actually lasted 9 years, and the decline in GDP amounted to almost 40 percent (since 1989).

During the years of independence of Ukraine, the highest value of GDP was reached in 2008. It amounted to 3322 USD. This indicator corresponds to the data from Fig. 1, which is presented in the study by Gatsenko [8]. In 2018, Ukraine GDP per capita amounted to 3110 USD [9]. Thus, the period of 1990-2018 was the period of long-term stagnation of the Ukrainian economy, which was replaced by the periods of recession: 1990-1998, 2008-2009 and 2014-2015. The Ukrainian economy still cannot achieve the constant of GDP per capita of 1989 .

To prove that the reason for the stagnation of the Ukrainian economy is exclusively internal and is not related to global processes, or to the collapse of the previously unified economy of the USSR, Figs. 3 and 4 are provided for comparison. Fig. 3 shows GDP per capita in Hungary over the period of 1985-2015 (Fig. 3) [10].

In 1985, Hungary's GDP per capita was 2139 USD. In 1989 , it amounted to 2893 USD. If we compare it with

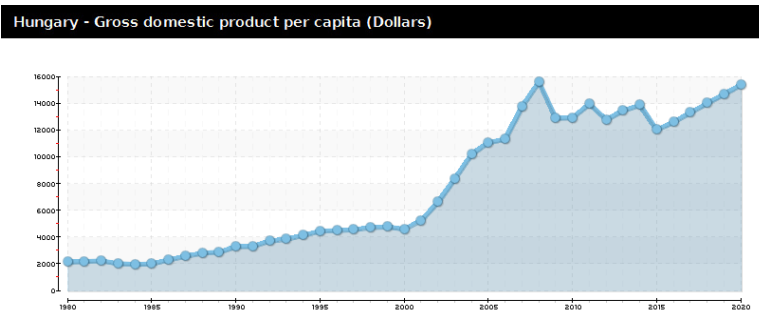

|III $\begin{aligned} & \text { Source : IMF } \\ & \text { Date : }: 2015 \\ & \text { creation: }\end{aligned}$

Fig. 3. Hungary: Ranking - GDP per capita (US \$) [10]

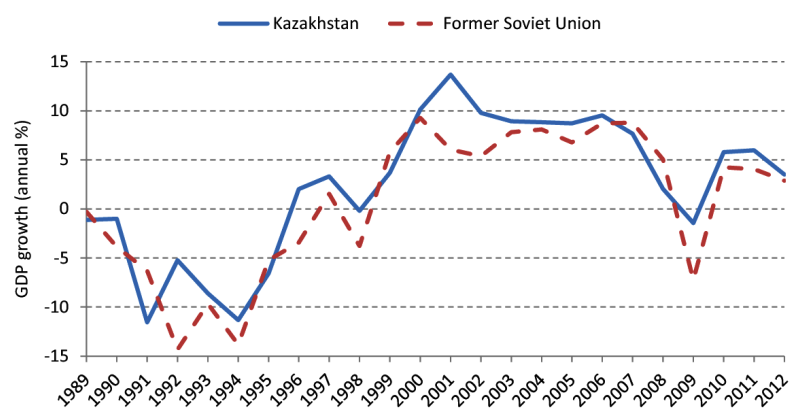

Fig. 4. Real GDP per capita growth in Kazakhstan, 1989-2012 [11] 
Ukraine's GDP of that period, in 1989 the economic development of Ukraine exceeded that of Hungary by about 70 percent. However, a further comparison of the figures confirms two obvious facts [10]:

1. The long-term stagnation of the Ukrainian economy is not related to global economic processes.

2. The main reason for the long-term stagnation of the Ukrainian economy over the years of independence is the extremely inefficient governance.

It is evidenced by the values in Figs. 2 and 3. In 1998, when under President Kuchma, Ukraine's GDP per capita reached its lowest value of 1686 USD, Hungary's GDP rose to 4723 USD. Within 8 years after gaining independence, the Ukrainian economy managed to degrade so much that it was almost 2.5 times inferior to the economy of Hungary.

In 2008, when Ukraine's GDP per capita reached its "peak" during the period of its independence and amounted to 3,322 USD, the same indicator in Hungary was already 15,588 USD. Thus, the difference between the best values of GDP per capita in Ukraine and Hungary was already almost 4.5 times not in favor of Ukrainian governance. In 2015, per capita GDP in Ukraine was 2828 USD, while in Hungary 12,021 USD [10]. The difference was approximately 5.5 times.

After the collapse of the USSR and previously unified economic system, many former Soviet republics truly experienced difficulties in rebuilding their national economies. However, in the CIS countries, unlike Ukraine, the period of economic recession lasted for a short period. The newly created states not only reached the GDP indicators of the USSR period, but also significantly surpassed them. As an example, the indicators of the GDP of the Republic of Kazakhstan can be offered. As we see from Fig. 4, Kazakhstan reached GDP per capita, which corresponded to the GDP growth rate of the Kazakh SSR in 1996. Moreover, in 1997, it exceeded this indicator (Fig. 4) [11].

It should be noted that the economies of other former Soviet republics, which cannot be not comparable with the potential of economy of the Ukrainian SSR, switched from recession to growth over much shorter time periods than Kazakhstan did. The economy of the Ukrainian SSR had the highest potential in the USSR, comparable with the potentials of the economies of the leading states of Europe in the 1990s: Germany, France, and Great Britain.

Thus, the statistical data from the World Bank confirm the long-term stagnation of the Ukrainian economy. It began in 1989, when GDP per capita of the Ukrainian SSR was 4243 USD and has continued to this day. In 2018, GDP per capita of independent Ukraine amounted to 3110 USD.

In one of the latest studies of the World Bank, the key macroeconomic indicators of Ukraine over the period of 2013-2020 are presented. [12]. The authors of the Finance Review note that the prolonged stagnation of the Ukrainian economy is explained by six key factors that are still ignored by the state authorities in Ukraine. These are demographic problems, poor quality of education, population inequality, insufficient adaptation of the governance model to globalization processes, managerial problems in the energy sector and its impact on the environment, and finally, excessive debts of consumers and the government. In 2017, the government and government-backed debt amounted to 89 percent of GDP [12].

Second, we prove the fact that all the branches of government in Ukraine ignore two key factors in the development of the economy: education and human capital.

The fact of educational practices succession is obvious in the world tradition [13, 14]. It guarantees succession of generations, as well as the transfer of fundamental cultural values and ideals. Despite the fact that Ukraine has one of the highest percentage of government spending on education in the world (6 percent of GDP), experts agree that Ukrainian education does not meet international standards. S. Kahkonen, the di- rector of the World Bank in Belarus, Moldova and Ukraine, called his article Why Ukraine's Education System is Not Sustainable [15]. Kahkonen identified three main reasons for the instability of education in Ukraine: 1) outdated teaching methods; 2) low morale among teachers due to low salaries and inadequate social significance of this profession; 3 ) a high level of corruption in education. In its conclusions, Kahkonen relies on the following statistics. Since Ukraine gained independence, the number of students in the school has decreased by 41 percent - from 7.1 to 4.2 million. However, over the same period, the number of schools fell by 11 percent, while the number of teachers fell by only 5 percent. This means that now there are nine students per teacher in Ukraine [15]. This is one of the lowest rates in the world, which confirms the inefficient spending of budget funds.

Fig. 5 testifies to the real significance of education in the nation's standard of living, as well as to a decrease in its quality (Fig. 5).

In 1990, the total number of scientists in Ukraine was 313079 people. In 2015, it decreased by almost five times and amounted to 63864 people.

By comparison, the opposite trend was observed in the world. This is evidenced by a study of Eric Gastfriend [16]. The results of the research by Gastfriend are presented in Fig. 6.

To assess the number of scientists, Gastfriend chose PhD's Granted, since in the world's practice, obtaining a scientific degree is regulated by the unified requirements. The results of the study were all taken by Gastfriend from the official websites of the Ministries of Education of the USA, Great Britain, Australia, India and China. Moreover, the US website presents the data for the period since 1900, while the websites of the Ministries of other states provide the information over the period since 1999 .

In addition, Gastfriend justified the exponential growth of scientists and the importance of science by comparing the number of patents granted and the number of published scientific papers over the indicated period [16].

The prestige of education and science in Ukraine is evidenced by a study conducted by the Organization for Economic Cooperation and Development (OECD) [17]. The results of the study were published in 2016. Among the most impressive figures, let us single out the comparison of the salaries of Ukrainian teachers and those from the 35 OECD countries. The salary of Ukrainian teachers was not only the lowest in Europe, but the difference in salaries was impressive. For

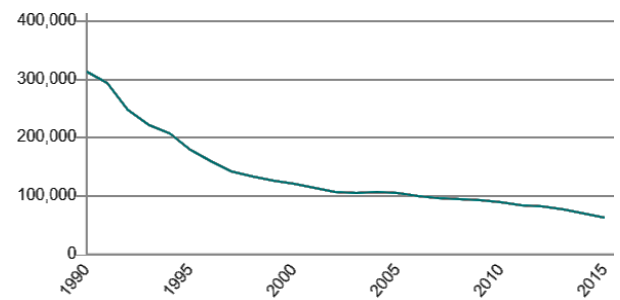

Fig. 5. The number of scientists in Ukraine 1990-2015 [1]

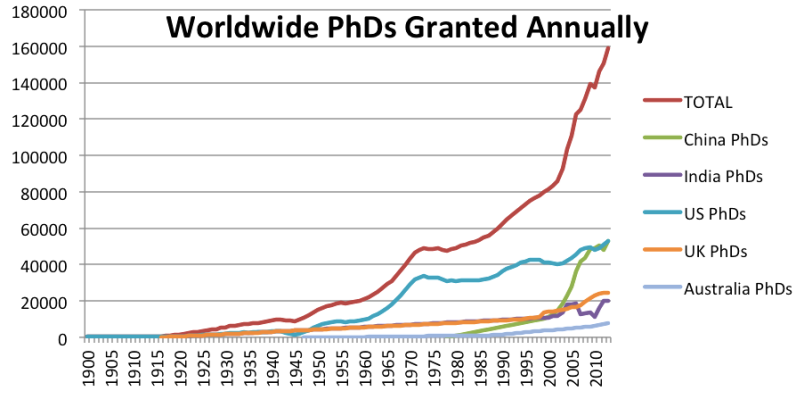

Fig. 6. Worldwide PhD's Granted Annually, 1900-2010 [16] 
example, the salary of Ukrainian teachers is 19 times lower than that of Polish teachers and 67 times lower than that of teachers in Luxembourg [17].

The comparable indicators can be distinguished when comparing the values of human capital potential in Ukraine with those of the European Union states.

In comparison with the European countries, human capital in Ukraine ranks $50^{\text {th }}$, one of the last places in Europe. By this indicator, Ukraine is ahead of Moldova (51 ${ }^{\text {st }}$ place) and Romania ( $67^{\text {th }}$ place) only. The Human Capital Index was first published in the World Development Report (WDR) 2019 [18]. The index shows which countries best mobilize the economic and professional potential of their citizens. The index is based on three indicators:

1. The proportion of children surviving after the age of $5(\%)$.

2. The amount of education (the expected number of students under the age of 18) and the quality of education (average test results).

3. Adult survival rates (percentage of 15 -year-olds who have reached the age of $60, \%)$ and health indicators of children under the age of $5(\%)$.

An important indicator of the state's attitude to human capital, or a key indicator in the relationship between the government and the people, is an indicator of national happiness. According to the World Happiness Report 2019, Ukraine ranks 133 out of 156 countries of the world by this indicator [19]. By comparison, Hungary ranks $62^{\text {nd }}$ and Poland $-40^{\text {th }}$. As this study found, all the states that have high levels of citizen satisfaction with the governance model have high values in six key variables, which support the welfare. This is the level of income, healthy life expectancy, social support, freedom, trust and generosity [19].

Fig. 7 shows a graph of natural population growth in Ukraine over the period 1950-2010 [20].

The lines denote the values per 1000 people: birth rate, death rate, and natural growth. As the graph shows, the natural population growth of Ukraine began to decline back in the time of the USSR. During the years of independence, this trend only intensified [20]. According to another source, since 1999, the population of Ukraine has decreased by about 15 percent, while the number of youth over this period has decreased by almost 25 percent [21].

Let us prove the third key thesis of our study: the dependence of economic growth on the increase in the quality of education and human capital.

As follows from the study Review of the Education Sector in Ukraine: Moving toward Effectiveness, Equity and Efficiency, since the time of gaining its independence, Ukraine has managed to maintain many of the educational benefits that it got after the collapse of the USSR [21]. However, the main problem is that the skills taught by the remaining "soviet" education do not correspond to the skills that are required in the

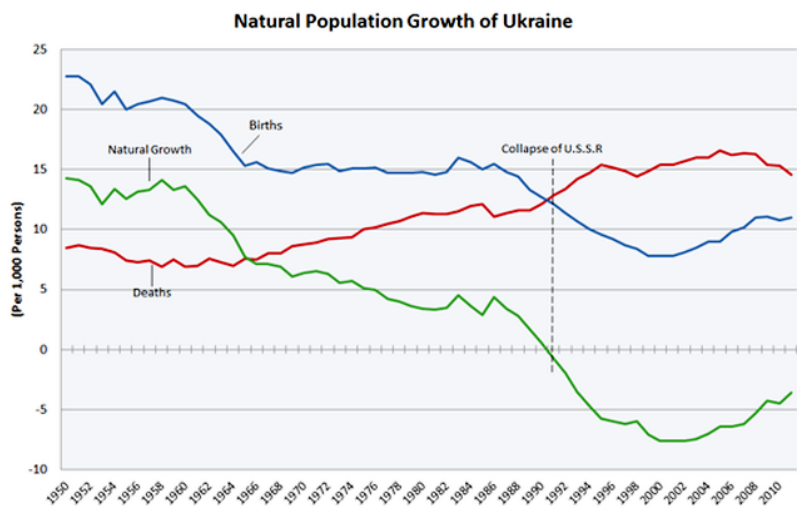

Fig. 7. The natural population growth of Ukraine (1950-2010) [20] governance models, economic, behavioral and other models that are brought into management from a completely different sociocultural environment. Despite the fact that some researchers urge to get rid of the "postcolonial syndrome" and form the Ukrainian management culture based on the traditions and attitudes of the national culture, the process of formation of Ukrainian culture has not been completed yet [22]. The key markers of modern national identity are only being formed and are taught in higher education institutions through the courses of philosophical disciplines for the degrees in International Management, Public Administration, and others. [23]. It takes time to form a new generation of managers whose worldview will be based on a new understanding of national culture. It is this generation that will be able to effectively use new markers of Ukrainian identity in governance models, and possibly combine the values of pre-Soviet, Soviet and postSoviet Ukrainian culture.

However, this process has not been completed yet. This fact is confirmed by the attitude to human capital in the management models used in Ukraine. According to the latest assessments of the welfare of states (141 states of the world), human capital in Ukraine is only 34 percent of the total national welfare [21]. Compared to 51 percent for low-income countries and 62 percent for Europe and Central Asia, this is the index that indicates a catastrophic underestimation, or rather ignorance of human capital in Ukraine. Low value of human capital reduces the value of national wealth, and, accordingly, the importance of Ukraine in global processes.

Exploring the history of the concept of "human capital", the place of education in this concept, as well as the impact of this concept on the development of economic theories, Hadley E. came to the conclusions that of importance for our study [24]. Firstly, the concept of "human capital" acquired its modern neoliberal form in the studies of the Chicago school of economists. It was the representatives of the Chicago school of economics in the second half of the twentieth century who proved the need to consider human capital as a necessary and promising form of investment. "Human capital" was formalized and presented as an important actor in economic theories. Depending on the state's attitude to "human capital", as well as on its share in national capital, it was capable of either ensuring the economic growth of the state, or leading to economic recession and long-term economic stagnation. Note that Theodore Schultz in 1979, and Gary Becker in 1992 received Nobel Prizes in Economics for creating theories based on the concept of "human capital". Secondly, the conception of investment in human capital was disclosed, i.e. the investment in the development of education, which ensured the continuous improvement of professional skills necessary for the intensification of production processes and, accordingly, the growth of the economy of the state [24].

In modern economic theories, on the basis of which the modern world economy is built and developed, human capital is considered in two aspects:

a) on a large scale, when investment in human capital is seen as such affecting national and global economic indicators;

b) on a small scale, when investing in people is considered as critical for the organization effectiveness.

The concept of human capital asserts that the main source of production potential, whether in the economy, organization or management, is the abilities of people, i.e. comprehensive disclosure of their internal potentials [13]. Therefore, any modern state development strategies that are prescribed by political parties, governments, expert groups, etc., necessarily include a strategy for the development of education. It is education and its development that ensures the future growth of the human capital potential. Reforming educational institutions is a prerequisite for modern economic theories. Only the reforms in the field of education are capable of providing the national economy with a high quality, purposeful, flexible and 
responsible workforce, able to meet the needs of industry and carry out reforms in other areas of the nation's life. Only through a reformed and highly effective educational system can the state achieve the growth of human potential, as well as benefit from human capital, i.e. directing its potential to economic growth and the development of other areas of activity.

In modern economic theories, it is an obvious and proven fact that a high rate of expenditures for education and development of employees is fully paid off with a higher value of their potential revealed by education. For this reason, management of modern enterprises stimulates and encourages training of their employees. Often enterprises pay for the training of their employees, and also provide a flexible work schedule that provides for the possibility of developing the human potential of the enterprise.

Conclusions. Thus, the results of our study prove that Ukraine has not created a governance model yet that is able to effectively manage the economy, science and social development. The main indicator of inefficient governance is the $133^{\text {rd }}$ place of Ukraine (out of 156 states) in the ranking of people's happiness rating in 2019. However, this indicator, in accordance with the resolution of the UN General Assembly adopted in July 2011, is the main guideline in the state policy.

We believe that one of the reasons for the lack of an effective governance model, with which it is possible to overcome long-term economic stagnation in Ukraine, is the underestimation of the key role of education and human capital in economic processes. The Ukrainian political elite and international management continue to consider the human capital using a traditional, instrumental approach. In Ukraine, human resources continue to be seen as expenses that must be kept beyond immediate and short-term needs.

\section{References.}

1. How Ukraine has changed in 25 years: graphs (2016). BBC News Ukraine. Retrieved from https://www.bbc.com/ukrainian/society/2016/08/160812_independence_day_charts_ko. 2. State Statistics Service of Ukraine (2020). Retrieved from http://www.ukrstat.gov.ua/.

3. Gross Domestic Product (GDP) (2020). Office for National Statistics. Retrieved from http://www.ukrstat.gov.ua/.

4. Statista (2020). Retrieved from https://www.statista.com/. 5. Khomenko, I. (2018). A Look at Informal Logic. Future Human Image, 9, 52-62. https://doi.org/10.29202/fhi/9/5.

6. Bucci, A., Prettner, K., \& Prskawetz, A. (Eds.) (2019). Human Capital and Economic Growth. Cham: Palgrave Macmillan.

7. Nie, B., Huang, X., Xue, F., Chen, J., Liu, X., Meng, Y., \& Huang, J. (2018). A comparative study of vocational education and occupational safety and health training in China and the UK. International Journal of Occupational Safety and Ergonomics, 24(2). https://doi.org/10.1080/10803548.2016.127004 $\underline{2}$.

8. Gatsenko, A. (2011). The Ukrainian Economy Has Not Been Able to Catch up With the Soviet. Komsomolskaya Pravda in Ukraine. August 19, 2011. Retrieved from https://kp.ua/ economics/296860-ukraynskaia-ekonomyka-tak-y-nesmohla-dohnat-sovetskuui.

9. World Bank (2020). Constant GDP per capita for the Ukraine [NYGDPPCAPKDUKR], retrieved from FRED, Federal Reserve Bank of St. Louis. March 22, 2020. Retrieved from https://fred.stlouisfed.org/series/NYGDPPCAPKDUKR. 10. Hungary: Ranking - GDP per capita (US \$) (2020). Actualitix 2020. Retrieved from https://en.actualitix.com/country/ hun/hungary-gdp-per-capita.php\#data-table.

11. Punthakey, J.J. (2018). Complementarities in Transition Economies: the case of Kazakhstan by. Retrieved from https:// www.semanticscholar.org/paper/COMPLEMENTARITIES-IN-TRANSITION-ECONOMIES-\%3A-THE-OFPunthakey/039d71a6b9098e021e7e20682219dcd8443c7556\# related-papers
12. World Bank (2017). Ukraine: Public Finance Review 2017. Washington, DC: World Bank. Retrieved from http://documents.worldbank.org/curated/en/476521500449393161/ pdf/117583-W P-P 155716 -final-output - PUB LIC-2017-06-28-23-16.pdf.

13. Bazaluk, O. (2019). Plato's Traditions in Modern Educational Theories. Annals of the University of Craiova - Philosophy Series, 43(1/2019), 5-20.

14. Rudenko, S. (2018). History of Ukrainian Philosophy: Teaching and Evaluation Methodology. Future Human Image, 10, 85-91. https://doi.org/10.29202/fhi/10/9.

15. Kahkonen, S. (2018). Why Ukraine's Education System is Not Sustainable. Retrieved from https://www.worldbank.org/ en/news/opinion/2018/09/12/why-ukraines-education-system-is-not-sustainable.

16. Gastfriend, E. (2015). $90 \%$ of All the Scientists That Ever Lived Are Alive Today. Future of Life Institute. Retrieved from https://futureoflife.org/2015/11/05/90-of-all-the-scientiststhat-ever-lived-are-alive-today/?cn-reloaded $=1$.

17. Education at a Glance 2016. OECD Indicators (2016). https://doi.org/10.1787/eag-2016-en.

18. World Development Report (WDR) 2019: The Changing Nature of Work (2019). The World Bank Group. Retrieved from http://documents.worldbank.org/curated/ en/816281518818814423/2019-WDR-Report.pdf.

19. Helliwell, J., Layard, R., \& Sachs, J. (2019). World Happiness Report 2019. New York: Sustainable Development Solutions Network. Retrieved from https://worldhappiness.report/ ed/2019/.

20. Demographics of Ukraine (2020). Wikipedia. Retrieved from https://en.wikipedia.org/wiki/Demographics_of_Ukraine.

21. Gresham, J., \& Ambasz, D. (2019). Ukraine - Resume Flagship Report (Vol. 2). Review of the Education Sector in Ukraine: Moving toward Effectiveness, Equity and Efficiency (RESUME3). Washington, D.C.: World Bank Group. Retrieved from http://documents.worldbank.org/curated/ en/884261568662566134/Review-of-the-Education-Sectorin-Ukraine-Moving-toward-Effectiveness-Equity-and-Efficiency-RESUME3.

22. Svyrydenko, D., \& Możgin, W. (2019).The Condition of Contemporary Ukrainian Culture: The Postcolonial Retrospective and Perspective. Ukrainian Policymaker, 4, 43-51. https://doi.org/10.29202/up/4/7.

23. Rudenko, S., Bazaluk, O., Tsvykh, V., \& Kalmuk, I. (2019). The Role of Philosophical Disciplines in Educational Strategies for Specialist Training in the Field of Public Administration. Naukovyi Visnyk Natsionalnoho Hirnychoho Universytetu, (3), 158-163. https://doi.org/10.29202/nvngu/2019-3/22.

24. Hadley, E. (2019). Human Capital. In: E. Hadley, A. Jaffe, \& S.Winter (Eds.). From Political Economy to Economics through Nineteenth-Century Literature. Palgrave Studies in Literature, Culture and Economics. Cham: Palgrave Macmillan. https://doi.org/10.1007/978-3-030-24158-2_2.

\section{Освіта й розвиток людського капіталу: від стагнації до рецесії в економіці України}

\section{Л. М. Харченко ${ }^{1}$, Л. Ю. Левченко ${ }^{1}$, В. В. Левкулич ${ }^{2}$ У.Я.Ханас ${ }^{2}$}

1 - Державний вищий навчальний заклад «ПереяславХмельницький державний педагогічний університет імені Григорія Сковороди», м. Переяслав, Україна, e-mail: harchenko_lora@ukr.net

2 - Державний вищий навчальний заклад «Ужгородський національний університет», м. Ужгород, Україна

Мета. Осмислення причини тривалої стагнації та рецесії економіки незалежної України на засадах статистичних даних. 
Методика. В якості головних методів дослідження автори використали методи описової статистики й логічної статистики. Також, автори скористалися компаративістським аналізом і моделюванням.

Результати. Головними результатами дослідження $є$ наступні:

1. Автори довели факт довгострокової стагнації економіки України, що почалася в 1989 році (4243 дол. ВВП України на душу населення) і триває до теперішнього часу. У 2018 році ВВП України на душу населення становив 3110 дол. Періоди 1990-1998, 2008-2009 і 2014-2015 були періодами рецесії.

2. Автори довели факт недооцінки в державному управлінні України двох ключових факторів розвитку економіки: освіти й людського капіталу. Згідно із «World Happiness Report 2019» Україна посідає 133 місце зі 156 держав світу, що підтверджує незадоволеність українців якістю державного управління.

3. Була доведена залежність росту економіки від зростання якості освіти та людського капіталу.

Наукова новизна. Спираючись на статистичні дослідження, автори довели:

1. Факт довгострокової економічної стагнації в Україні, що почалася в рік здобуття Україною незалежності та триває до теперішнього часу.

2. Головною причиною негативних сценаріїв у розвитку економіки України за період Незалежності є нехтування зв'язком між освітою, людським капіталом і національною економікою в моделі державного управління.

Практична значимість. Результати дослідження можуть використовуватися в моделях державного управління, а також економічних, поведінкових і інших моделях. Дослідження актуалізує цінність освіти й людського капіталу, а також доводить їх вплив на економічне зростання держави.

Ключові слова: людський капітал, освіта, моделі управління, національна економіка, довгострокова стагнація

\section{Образование и развитие человеческого капитала: от стагнации к рецессии в экономике Украины}

\section{Л. Н. Харченко ${ }^{1}$, Л. Ю. Левченко ${ }^{1}$, В. В. Левкулич ${ }^{2}$,} У.Я. Ханас ${ }^{2}$

1 - Государственное высшее учебное заведение «Переяслав-Хмельницкий государственный педагогический университет имени Григория Сковороды», г. Переяслав, Украина, e-mail: harchenko_lora@ukr.net

2 - Государственное высшее учебное заведение «Ужгородский национальный университет», г. Ужгород, Украина
Цель. Осмысление причины продолжительной стагнации и рецессии экономики независимой Украины на основе статистических данных.

Методика. В качестве основных методов исследования авторы использовали методы описательной статистики и логической статистики. Также, авторы воспользовались компаративистским анализом и моделированием.

Результаты. Главными результатами исследования являются следующие:

1. Авторы доказали факт долгосрочной стагнации экономики Украины, которая началась в 1989 году (4243 дол ВВП Украины на душу населения) и продолжается до настоящего времени. В 2018 году ВВП Украины на душу населения составлял 3110 дол. Периоды 1990-1998, 2008-2009 и 2014-2015 являлись периодами рецессии.

2. Авторы доказали факт недооценки в государственном управлении Украины двух ключевых факторов развития экономики: образования и человеческого капитала. Согласно «World Happiness Report 2019» Украина занимает 133 место из 156 государств мира, что подтверждает неудовлетворенность украинцев качеством государственного управления.

3. Была доказана зависимость роста экономики от роста качества образования и человеческого капитала.

Научная новизна. Опираясь на статистические исследования, авторы доказали:

1. Факт долгосрочной экономический стагнации в Украине, которая началась в год обретения Украиной независимости и продолжается до настоящего времени.

2. Основной причиной негативных сценариев в развитии экономики Украины за период независимости является пренебрежение связью между образованием, человеческим капиталом и национальной экономикой в модели государственного управления.

Практическая значимость. Результаты исследования могут использоваться в моделях государственного управления, а также экономических, поведенческих и других моделях. Исследование актуализирует ценность образования и человеческого капитала, а также доказывает их влияние на экономический рост государства.

Ключевые слова: человеческий капитал, образование, модели управления, национальная экономика, долгосрочная стагнация

Recommended for publication by T. A. Zhyzhko, Doctor of Philosophical Sciences. The manuscript was submitted 18.11.19. 